\title{
Management of Quality Improvement on Course and Training Institutions
}

\author{
Purwanto *, Aslamiah, Metroyadi \\ Master Program of Education Management, Universitas Lambung Mangkurat, Banjarmasin 70123, Indonesia
}

\section{Article history:}

Submission August 2020

Revised September 2020

Accepted October 2020

*Corresponding author:

E-mail: purwanto.bejebe@gmail.com

\begin{abstract}
Course and Training Institution (LKP) comes in informal education intending to prepare the ready to work students and increase their quality of life. However, some problems are faced by LKP. That is why; the number of LKP which are still operated at present is decreasing significantly. To solve this issue, this research aims to describe several things, such as (1) program planning; (2) program implementation, (3) program evaluation in quality improvement; and (4) the obstacles faced by LKP. The data collecting techniques used in this research are observation, interview, and documentation. The data analysis is done qualitatively by using the model of interactive analysis. It comes in three different steps. Those are data reduction, data display, and conclusion drawing/verification. Based on the data analysis result, it was found that: (1) LKP program planning is done every beginning of the year by considering 8 national education standards; (2) program implementation is done by giving $70 \%$ practice portion and 30\% theory; (3) program evaluation is done through the summative test and partnership evaluation. Meanwhile, the evaluation quality enhancement is done by using 8 standards of national education; and (4) the obstacles faced are the lack of students' desire for the available program studies so that the programs are then closed. The efforts done by LKP is by giving the job guarantee, provision of dormitories, and innovation by opening the new program studies. From those findings, it is recommended that the head of BP-PAUD Dikmas must create cooperation with the Labor Institution to distribute the LKP graduates. Besides, the LKP management must increase the partnership and expand its networking and program through training and skill cooperation with the business and working world.
\end{abstract}

\section{Introduction}

Education is an effort to prepare students through guidance activities, learning, or education; and/or training for its role in the future era (Sudjana, 2004). Concerning non-formal education, in the National Education System Law 2003 the terms formal, non-formal, and informal education are reused. The role of education as a development effort has the function of increasing social awareness, increasing the number of skilled workers, and increasing trained resources. According to Triant (2010) Education that can support future development is education that can develop the potential of students to face and solve life problems faced. Similarly, Sudarsana (2016) reveals the challenges of the world of education, including increasing added value.
To increase the community's economy and potential, there are non-formal education programs as an empowerment effort which is carried out to meet the diversity of quantity and quality of community that needs it. According to Ishak (2012) a non-formal education, as a type of education that is related to lifelong education, both of which have the same goal, namely to survive and sustain life, and to improve the quality of life. According to Hadi (2012), The Course and Training Institute (LKP) is part of the non-formal education process to improve the quality and productivity of human resources.

LKP is one of the non-formal education programs for people who need knowledge, skills, life skills, and attitudes to develop themselves, develop their potential, job, work independently, and 
or continue their education to a higher level(Minister of Education and Culture, 2013). Law Number 20 of 2003 on the National Education System article 26 paragraph 4 states that LKP together with other educational institutions is included in the Nonformal Education unit. In paragraph 5, it is explained that courses and training are forms of continuing education to develop students' abilities with an emphasis on mastering skills, competency standards, developing entrepreneurial attitudes, and developing professional personalities.

According to Latchem (2014), non-formal education takes many forms: namely in the form of second or part-time education for those unable to attend regular classes: youth clubs with substantial educational objectives; adult and continuing education; community education; personal development programs such as cultural language programs, fitness and sports; and professional and vocational programs for unemployment and an increase in the workforce.

Non-formal education is education that has advantages in the flexibility of a curriculum that is tailored to the needs of students and a learning process that emphasizes work skills (Grajcevci \& Shala, 2016). Next, the existence of a non-formal education must be empowered to support formal education to reach the whole education aim (Moldovana \& Boco, 2015). The non-formal institutions studied were LKP. In Government Regulation number 73 of 1991, it is explained that the course is an out-of-school education unit consisting of a group of community members who provide knowledge of certain mental skills and attitudes for learning citizens.

Courses are educational activities that take place in society that is carried out deliberately, organized, and systematically to provide certain subject matter to adults or adolescents in a relatively short time to acquire knowledge, skills, and attitudes that can be used to develop themselves, and society (Hatimah \& Sadri, 2014). Meanwhile, according to Irianto (2011) training is the act of increasing the knowledge, and skill of an employee for doing a particular job. Unfortunately, according to the data submitted by the Directorate General of Courses and Training (2019), The number of LKPs is currently experiencing a significant decrease due to the quality of management that is not good enough that it is unable to compete with for- eign profit training courses. For this reason, educational institutions that organize non-formal educational institutions require performance quality management as measured by quantity, management quality, and product quality.

Explained by Prihantoro (2012) Quality control system in general, there are four aspects related to the quality control system, namely input, output, system, and process. Inputs are external stimuli that are applied to a control system to obtain certain responses from the regulatory system. The output is the actual response obtained from a control system. The Ministry of Education and Culture stated that the success indicators of improving the quality of learning management in LKP can be seen through the achievement of input, process, output, and outcome indicators. Increasing the quality of service courses and training for the community. Participants in the activity program can apply quality management and learning systems for courses and training in their respective institutions (Ministry of Education and Culture, 2016).

As an institution that plays a role in development through human resources through non-formal education in South Kalimantan, it requires good management and management at LKP. Researchers took the location at LKP Kharisma because the location was motivated by several considerations, namely as an educational institution with performance A predicate and has been accredited by BAN PAUD and PNF. The institution implements quality improvement management consisting of planning, implementation, and evaluation.

Based on the description above, the purpose of this study is to identify and describe. It is also to explain in depth the management of quality improvement of non-formal educational institutions at LKP Kharisma Banjarmasin. The research objective of this research is to describe and explain in detail in detail the following: (1) program planning; (2) program implementation, and (3) program evaluation; and (4) obstacles faced by the institution in improving the quality of the institution.

\section{Material and Methods}

This research uses the descriptive-qualitative approach with a case study research plan which is done to describe and explain deeply how to in- 
crease the quality of non-formal education institutions is. Those are by doing the planning, implementation, and evaluation.

The location of this research is done in LKP Kharisma, Banjarmasin city, as an LKP which gives training, education, and increase skills for students. The research subjects were directors, tutors, and staff. Obtaining data and information using data collection techniques through 1) Observation, which is called the data collection. It is done by seeing, observing, and analyzing what is the object. In this case, the authors do this by participating in educational program activities at LKP Kharisma; 2) interviews, namely data collection carried out by asking questions to the respondents who were the sources; 3 ) Documentation, namely the process of taking pictures at the time of research.

The data analysis technique chosen in this study is a qualitative analysis technique with an interactive analysis model consisting of three stages. These stages include data reduction, display data, and conclusion drawing/verification (Miles, Huberman, \& Saldana, 2014).

\section{Results and Discussion}

Finding in LKP Kharisma was about quality enhancement management. Those were varied from the planning, implementation, evaluation, and obstacles faced.

\section{Planning}

Planning activities carried out at the beginning of the school year which includes learning planning activities, partnerships with companies as internships for students and quality institutions through planning 8 (eight) quality standards. Planning implemented in Training Institutions and Courses consistent with operational scope and objectives. It is through planning that the Training and Course Institutions (LPK) have a management system that is ready and able to guarantee highquality education and training in South Kaliman$\tan$.

Learning planning activities include course learning activities and 1 (one) year training. Learning courses as an effort to foster students through short learning activities with a period of 3 to 6 months are adjusted to the demands of both the community and market needs. Courses emphasize students in developing abilities and potentials so that students can apply them in their work or life. This finding is in line with the results of research by Husein and Sutarto (2017) that the sewing course implementation phase is held every month. Those are on Tuesday, Wednesday, and Friday with a duration of 2 hours. Learning citizens can use the media according to the instructions from the tutor by understanding the stages of the sewing course learning material.

Other research by Rosyid Faizin et al. (2019) that learning planning at the Al-Azhar Arabic Language Course Institute is planned from the shortterm dimension of time. The course planning is divided into four parts, namely 1) 2 (two) week program with boarding facilities; 2) 1 (one) month program with 4 sub-language class activities; 3 ) vacation programs with options of one week, two weeks, and three weeks; 4) special program during the month of Ramadan with a period of two weeks and one month. The 1 (one) year training planning activity consists of Accounting \& Office Computers (AKP), Information Management \& Computers (MIK), Information Engineering (IT), and Automotive Engineering (TO) as well as Hospitality and Cruise Ships (PKP). This finding is in line with Santi's research (2018) that educational and training programs or majors offered by these educational and skills institutions are of the same type and are considered to represent the current trend needs of the world of work. As an educational and skills institution with an educational period of 1 (one) year, it ends with an apprenticeship program to prepare human resources who are ready to compete in the world of work and entrepreneurship. Other findings by Sufyan, Nurhalim, \& Shofwan (2019) that the Package C program learning planning is a systematic process in making decisions about behavior to be taken in the future to achieve learning objectives related to student functional and entrepreneurial skills.

Partnership planning is with the Directorate of Course and Training Development, Senior High/Vocational Schools and the Business World, and the Industrial World through the company. Those are the institutional efforts in establishing cooperation that can increase learning activities and activities in the world of work. It is in accordance with the opinion of Notoatmodjo (2010) partnership is a formal cooperation between individuals, groups, or organizations to achieve a specific task or goal. Meanwhile, according to Herlina 
(2018), the main key to implementing the partnership is to implement coordination, integration, and synchronization of all programs with related institutions participating in the partnership and applying the principles of mutual need, mutual strengthening, and mutual benefit.

This partnership plan is in line with Sujanto's research results (2016). He stated that partnership is a cooperative relationship carried out by two or more parties within a certain period to achieve mutual benefits/goals with the principle of mutual need as outlined in the form of a memorandum of understanding or a Memorandum of Understanding (MoU) document. Collaborating with DUDI is very important for the survival of LKP. Without building partnerships, it will be difficult for LKP to develop considering the tighter and tougher competition. The conclusion is that the private sector partnership (DUDI) in education is a tool for achieving development in a country, especially in the field of education to prepare, and develop skills in increasing human resources through job training.

The findings regarding partnership planning activities with the Central Government are through submitting proposals to the Ministry of Education through the Directorate of Course Guidance and Training and analyzing targeted students through the Manpower Office.

This finding is in line with the results of Hapsari's research (2017) that the preparation of the workforce is carried out with competencybased training through types of training, certification bodies, and the needs of the business and industry. PP-PAUDNI Regional II Semarang is developing a course learning model and training as an institution that provides courses and training to conduct studies on appropriate course program models and easy certification because the institution is ready and graduates can be absorbed. Partnership with vocational high schools (SMK) is through good communication so that LKP Kharisma can socialize with all SMA / MA and SMK throughout South Kalimantan. Another partnership is with SMK that LKP Kharisma is one of the apprenticeship recommendations for vocational students in carrying out the apprenticeship subject program. These findings are in line with Fredian's research (2018) planning the collaboration process between SMK 12 Surabaya majoring in Monday music by establishing a collaborative relationship with competent DUDI to support the potential of students to be able to learn with curriculum or school competencies. The main goal is to provide students with direct experience to experience the world of work, a place to develop their potential and creativity.

The finding of a form of partnership with the business world and the industrial world is through cooperation through memoranda of understanding with companies engaged in services, hotels, and offices. It is following Kamil's opinion (2010) that in planning, what is concerned is to agree so that the roles and responsibilities of each party as outlined in a memorandum of understanding or $\mathrm{MoU}$ are then carried out by signing the cooperation agreement.

Planning for quality improvement through 8 (eight) quality standards of non-formal educational institutions, namely: 1) standard of graduate competence is planning for graduates who are ready to work, prepared through their skills, expertise and attitudes, business capital and employment fields; 2) standard content with competencybased SKKNI curriculum planning activities, the amount of learning load in the 1 (one) year training program and courses and education calendar as a reference in learning activities; 3) standard interactive learning planning process, syllabus, lesson plans, materials and learning activities in class and internships; 4) standards of educators and education personnel with instructor planning activities in learning and the recruitment of instructors in partnership companies; 5) standard infrastructure, namely planning activities to fulfill learning infrastructure in classrooms and workshops, provision of dormitories where students live; 6) management standards, namely student recruitment, training needs analysis, alumni management and learning readiness; 7) financing standards with planning costs of educational activities and training costs and 8) standard assessments by planning course learning assessments, 1 (one) year training and training.

This planning is in line with a research done by Jayadi et.al., Jayadi, Zulkarnain, \& Sofino (2017) in the LKP EEC management that; 1) graduate competency standards by formulating graduate profiles, competencies, graduate indicators, and learning outcomes; 2) content standards by compiling core materials and supporting materials based on graduate competencies, curriculum 
structure, making types of student basic competency elements, conducting curriculum evaluations with an analysis of the needs of the world of work, preparing learning loads according to the curriculum, preparing continuous learning and making an educational calendar and calendar of registration schedule and socialization through online media; 3) standard process by preparing and compiling syllabus, lesson plans, learning tools, education and student ratios, monitoring and evaluating the results of the supervision process; 4) educator and education standards by preparing instructor academic qualifications with a minimum of a bachelor's degree, and having a certificate of examiners; 5) standard facilities and infrastructure with the preparation of teaching materials in the form of modules, educational props, books in the library, and learning media. It is also done by preparing the land, buildings, and facilities; 6) management standards by preparing educational qualifications and competencies for leadership, preparation of assignments, learning time, partnerships, similar LKP, alumni data collection, evaluation of programs, and performance; 7) financing standards by preparing and compiling a budget for the RAB (1 year) cost and typical bookkeeping and main sources of finance; 8) assessment standards by preparing and compiling final assessments and providing learning outcomes documents.

Planning an educational program is very important to be implemented. It is because planning has a significant effect on the quality of education (Alawamleh, Bdah, \& Alahmad, 2013). Especially in educational programs that emphasize work skills. Planning educational programs will help ensure that students will acquire the skills expected by business and industry. Because with good planning, everything that is needed can be better prepared, especially those related to the facilities and infrastructure needed to support the learning process (Escobar, 2019; Nepal \& Maharjan, 2015).

Besides, good planning will make the learning process is also better, and having more quality. It will make the students are more motivated and reach the skills needed (Serbes \& Albay, 2017). Furthermore, good planning will have an impact on the continuity of an education institution (Filho, et al., 2019). Since the planning of an education program is so crucial, the involvement of teachers on this planning is a must (ball, Knobloch, \& Hoop, 2007). It is because education will become the executor of that planning.

\section{Implementation}

The implementation activity is to implement the whole planning activities. In this implementation activity, the learning result of students is highly influenced by the teachers' quality (Poernamawijaya, Sulaiman, Suriansyah, \& Dalle, 2018). It is for the implementation of learning activities, partnerships, quality improvement. At this stage, the instructor conducts teaching and learning interactions through the application of various strategies, learning methods, and techniques as well as utilizing a set of media. Implementation of learning, namely 1 (one) year courses, and training for 2 semesters with internships in the second semester. Course learning with face-to-face activities for 12 meetings with a duration of 120 minutes in 1 (one) face-to-face meeting is essential.

The findings regarding the implementation of 1 (one) year training with the implementation of learning activities, there are two activities, namely classroom learning programs and apprenticeship activities. The learning materials provided include supporting theoretical materials and skills and practical materials on campus. It is according to the level. Overall, the theoretical material is $30 \%$, and the practice material is $70 \%$. The findings regarding the implementation of this 1 (one) year training are in line with Kamil's opinion (2010) those are the apprenticeship training/learning by doing a model or the apprenticeship. Another study was done by Asshidiqy (2016). It states that the learning method is applied to students by applying $30 \%$ theory and $70 \%$ practice. It is to improve the ability of students to apply the knowledge, expertise, and skills they have acquired.

The findings regarding the course learning activities were 120 minutes of activities. It is consistent with the research results of Rizaldi and Sutarto (2017) which states that in course learning activities begin with preliminary activities for 10 minutes, core activities for 105 minutes, and closing activities for 5 minutes. Other researchers were done by (Aningtiyas, Fakhruddin, \& Ilyas (2012) in the implementation of learning music courses using theoretical and practical methods 
simultaneously. They stated that the process of interaction and communication through discussion and question and answer. Other research was done by Wahyuni and Sutarto (2018) that the implementation, of course, activities are guided by the objectives and learning materials with theoretical and practical methods.

The implementation of partnership activities with the central government is through superior entrepreneurship training (PKWU) and leading job skills training (PKKU) with 30\% theoretical activities, and $70 \%$ practical activities. This implementation is in line with the research results of Herlinda, Hidayat, \& Djumena (2017) with the implementation of training activities that use learning citizens as many as 20 people with a meeting duration of 3 hours held from Monday to Thursday starting from October 5, 2016, to November 21, 2016. The ratio of the theory is $30 \%$ and $70 \%$ practice.

The implementation of the partnership with SMA / $\mathrm{K}$ is to become an apprenticeship for vocational students. The implementation of partnership activities with the business world and the industrial world is through companies in which institutional students carry out apprenticeship activities. This finding is in line with the results of research by Satria, Supadi, \& Listyasari (2017) that the implementation of the Al-Azhar High School partnership activities collaborates with LBPP-LIA and the native speaker procurement program conducted with the LP3I Course center.

Implementation with the business world and industry is through apprenticeship activities carried out by students at partner companies. These findings are in line with Pradikto's research (2017) which stated that LKP Dress Making collaborated with partners in the form of apprenticeships. The implementation is carried out at garment factories in Bandung and several independent business places. Collaboration in the business world and industry is useful for the placement and strengthening of students' independent businesses.

Implementation of quality improvement through 8 (eight) quality standards of non-formal educational institutions, namely: 1) graduate competency standards, it is called the implementation of graduate competency standards through learning activities, implementation of internships, and practice; 2 ) standard content of learning programs, program level; basic competencies related to graduate competency standards; learning materials; course weights; learning modules and loads; 3 ) standard process derived from the syllabus into a Learning Implementation Plan (RPP), learning materials tailored to the needs of the business world, and industry; 4) education standards and educational personnel are the fulfillment of instructors, staff, and improvement of managerial abilities; 5) standard facilities and infrastructure, namely the completeness of learning facilities; 6) management standards which is called the educational, managerial programs by directors and recruitment; 7) financing standards for recording educational activity transactions in bookkeeping; and 8) performance appraisal standards as an effort to improve the quality of education.

The findings of this study are in line with Sujanto's research (2016) which revealed that to improve the quality of management; LKP must study eight (8) national education standards to be applied in administering education which includes: Graduate Competency Standards, Content Standards, Process Standards, Teachers and Education Personnel Standards, Facilities and Infrastructure Standards, Standards management, Financing standards, and Appraisal standards. Another study by Mahampang (2016) namely the management's fulfillment of the quality assurance standards of the Ar-Rum LKP institution, namely: 1) standard content includes: curriculum, study load, and educational calendar; 2) standard process includes: syllabus and learning process plan (RPP); 3) Competency standards of Graduates include: achievement of competencies according to the level / level that is followed; 4) Educators and Education Personnel standards include: teaching staff consists of four people who have national qualifications and the educational staff is the head of the institution; 5) standard infrastructure includes: the availability of facilities and media for learning activities; 6) management standards are implemented as needed because there is no annual work plan; 7) financing standards have not been standardized due to the absence of an orderly financing design and recording of financing, financing is still mixed between investment costs, personal costs and operational costs; and 8 ) assessment standards, namely the results of the practice of making products according to the 
levels, and levels that are followed. The implementation of learning has a very vital role in producing graduates who have the knowledge, skills, and attitudes expected by the curriculum. Therefore, each component of the implementation of learning must be ensured to have the expected quality. For example, the quality of lecturers, where each teacher must have a quality that is following national education standards. The quality of the instructor will greatly determine the learning outcomes (Kaplan \& Owings, 2001). Likewise, the involvement of students in the teaching and learning process will also affect student achievement (Delfino, 2019). So, in the learning process, the teachers are obliged to activate students.

\section{Evalution}

The evaluation activity of learning management is in line with an opinion from Hamalik (2008). It is said that the learning evaluation functions and aims to develop and improve the quality of education for accreditation of institutions and also to determine the impact of learning activities.

Evaluation of learning programs that are carried out to analyze education and training programs tailored to the needs of the community, and industry needs, as well as evaluation of learning in an assessment format carried out to meet graduate competencies. This finding is in line with Wiyoko's opinion (2010) which states that program evaluation is defined as a systematic and continuous process for collecting, describing, interpreting, and presenting information about the implementation of learning program designs that have been compiled by teachers to be used as a basis for making decisions, compiling policies and developing further learning programs.

Evaluations carried out in learning programs carried out at 1 (one) year training, courses and training are learning evaluations with a theory material assessment format as much as $30 \%$, and practical material as much as $70 \%$. This finding is also appropriate with the research that comes from Rizaldi and Sutarto (2017) who said that the evaluation of the entire learning component must be done more intensively so that if there is a sudden need it can be resolved more quickly. Other research by Abbas, Sari, Nasra, \& Elihami (2020) said that the evaluation of learning outcomes carried out by LKP Dian Ayu includes an assessment of attendance, understanding of learning materials both theory and practice and ends with a local competency test. Other research by Sucipto and Sutarto (2015) stated that the evaluation carried out at LKP Elisa Tegal through formative tests and summative tests consisted of written and practical tests while attending a sewing course for 3 months. Another study by Septyana(2013) said that the final stage in the training activity is a formative evaluation carried out at the end of each lesson and a summative evaluation at the end of the semester to determine the next action regarding learning outcomes. Test evaluation techniques by giving assignments and non-tests by observing the understanding of the material by students.

Evaluation of course learning with those carried out at the end of the meeting. Evaluation through theoretical assessment activities regarding the material obtained and practice. This finding is in line with Ningrum (2015) who stated that the learning outcomes of students in theory and practice with clothing designing activities show that the sewing course program is successful in empowering women. Other researches were done by Aningtiyas, Fakhruddin, \& Ilyas (2012) which said that Music course evaluation is carried out after each material after 16 meetings. The exam is in the form of practice by performing two songs.

Evaluation of partnerships so that institutions obtain quality and quantity achievements as measured from the partnership aspect by reporting training activities with the Directorate of Course Guidance and Training and the Manpower Office.

Partnership evaluation with the Directorate of Course and Training Development is by evaluating students' assessments on training activities through theoretical and practical activities. In line with the research results, Devi and Shaik (2012) also found that implementing agencies must evaluate whether the training \& development program is effective and gives the desired results. Proper evaluation is the basis for effective training. Training evaluation should become a regular system with the fact that the trainees are a temporary group. They attend training programs to acquire specific skills and return to work to apply them.

Other research by Sa'dhiyah (2016) also stated that with partnership evaluation activities using the BBL (Bridging, Bonding, and linking) model, where the course manager carries out bridging with partners through exploration, identification, 
and analysis of institutional needs. Bridging produces the following networks: 1) Director General of PAUDNI and the Office of Education, Youth and Sports of the City of Salatiga in terms of funding and course facilities, 2) CV. Ganesha, Solo in apprenticeship and placement of graduates, and 3) Puzzle IQ, Yogya to facilitate product distribution. The signing of a memorandum of understanding and active involvement of partners during the course strengthens bonding. The Office of Education, Youth, and Sports of the City of Salatiga actively participates in program priorities and operational program development through financing and providing course facilities.

These findings are in line with Fredian's research (2018) that the evaluation of the cooperation program of SMKN 12 Surabaya with the business world and industry (DUDI) is carried out at the end of the school year until the new school year for the smooth running of the annual program in the form of an internship.

Evaluation of partnerships with Vocational High Schools (SMK) through internships and assessment of aspects of work ethics, attitudes, and social relations of interns. The evaluation of partnerships with the business world and the industrial world is about the benefits of the partnership so that it can advance education at LKP Kharisma and determine the quality of LKP Kharisma as a reliable workforce coach through learning at LKP Kharisma.

The findings regarding SMK partnerships through apprenticeship activities are in line with Pradikto's research results (2017) that LKP Dress Making is a place for apprenticeship for vocational and university students, a place for field work practice, observation, student research, and a sewing competency test site at the level of Cimahi City and the surrounding area.

The findings regarding the evaluation of partnerships with the business world and the industrial world through partner companies are in line with the results of Putra and Hariyati's research (2017) who said that the evaluation process of the cooperation between SMK Negeri 5 Surabaya with the business world and the industrial world was by using a questionnaire sent during monitoring in the industry.

Evaluation points include attitudes, and abilities, competencies obtained, jobs received, and activities in an internship in industry. The synergy of the evaluation role in determining the success of cooperation based on the absorption of vocational graduates.

Evaluation of education quality through 8 (eight) standards to determine the feasibility of education and training programs implemented as an effort to meet government standards by analyzing the needs of the community, and the need for skilled resources in the future. In line with the research results of Yusra, Sumarno, \& Burhanuddin (2017) Evaluation at the Institute of Dance Education at the BI Foundation is self-evaluation, evaluation, and curriculum development as a learning plan, evaluation of the empowerment of educators and education personnel, and accreditation. Other research by Istiqomah, Fakhruddin, \& Utsman (2017) done by evaluating the quality of equality education services at PKBM Citra Ilmu using the CIPPO concept (context, input, process, product, and outcome). Other research by Gustini, Alexon, \& Trudjai (2017) argued that by evaluating the quality of 8 (eight) standards, it can meet good indicators. The achievement of the implementation of 8 (eight) national education standards in the English for Children program at CCPJ is largely following the LKP accreditation standards from the National Accreditation Board for Early Childhood Education and Nonformal Education. Continuous evaluation activities will ensure the quality of educational programs carried out by an educational institution (Bij, Geijsel, \& Dam, 2016).

\section{Resistance}

In the quality improvement management activities at LKP Kharisma, there are several obstacles faced. Based on the findings in LKP Kharisma, some departments are closed due to a lack of public interest and intense competition with course institutions and universities in South Kalimantan. This finding is in line with the results of research by Hussein and Sutarto (2017) that the inhibiting factor faced at the Nissan Fortuna LKP was that the learning time was less effective and limited because it was not following the needs of the learning community in solving the practice and the problem of school attendance who did not arrive on time.

Efforts to overcome obstacles are to provide solutions provided by LKP Kharisma, namely: 1) providing job security to students and alumni who have not yet got a job; 2) provide a place to live 
that is guaranteed security, a location close to LKP; and 3) innovation by opening new majors following the development of science and technology and according to the needs of students through training activities. Giving knowledge about the latest technology used in the business and industry is very important for students. It is because the application of technology is a must in increasing competitiveness in today's digital era (Dalle \& Mutalib, 2018).

The finding of this ready to work guarantee is in line with research conducted by Asshidiqy (2016) which states that with the supporting factors through the LKP Surabaya Hotel School partner network that is widespread and strong so that graduates can be quickly absorbed by employment opportunities. The institute also provides a center for information on job vacancies and recruitments. Another study by Yulianingsih (2017) that students who pass the competency test at LKP Modes Muria Sidoarjo will be channeled to existing production units following the skills taught or guided as entrepreneurs. Students after being declared passed the next are to get job opportunities with partner business entities.

The findings regarding providing housing for these students are in line with the results of Sa'idah's research (2017) that said that to create quality Arabic learning, students by providing an Arabic/bi'ah Arabiya language environment, quality, and cheap, on time, boarding and Milad programs. This boarding program supports learning at the Arabic language course institution Al-Farisi Pare. Other research by Arya and Endrawijaya (2017) stated that in the framework of serving cadets/cadets by providing dormitories. Regarding services both in the field of comfort and a sense of security and satisfaction so that cadets can survive to live, and as a necessity in the hostel while participating in education and training for 3 (three) or 4 (four) years. The findings regarding the innovation of this course department are in line with the research results of Saad, Yusoff, \& Yassin (2011) that by making innovation in teaching a virtue.

\section{Conclusion and Recommendation}

Based on the explanation above, it can be concluded that quality management improvement in LKP Kharisma covers the activities of planning, implementation, and evaluation. The quality improvement through planning is done by several kinds of plannings which are covering the learning planning, partnership, and achievement planning of 8 (eight) national education standards.

The quality improvement through learning implementation is done by planning implementation and partnership to increase the quality of graduates and work distribution. The whole implementation activities refer to the effort to fulfill the 8 (eight) standards.

From the evaluation side, quality improvement is done through an evaluation implementation of the learning program. Those are an assessment of learning in 1 (one) year training, course, and training. It is also included the evaluation of 8 (eight) standards in the effort to reach the accreditation achievement.

Based on the finding of this research, the researcher recommends the head pf BP-PAUD Dikmas of South Kalimantan as a stakeholder regarding the management system of non-formal educational institutions to build cooperation with the Manpower Office so that the institution can improve the quality of LKP management. It is also hoped that the managers of educational courses and training institutions will increase partnerships, and expand networks and programs through cooperation with the business world and industry at home and abroad. Thus, graduates are quickly absorbed and LKP can become a non-formal educational institution that is in demand by the community.

\section{Acknowledgment}

The author thanks the Head of BP-PAUD DIKMAS South Kalimantan and all employees, directors, tutors, and staff at LKP Kharisma as a place of research, and all lecturers and academic staff at Lambung Mangkurat University Education Management.

\section{References}

Abbas, M. A., Sari, N., Nasra, \& Elihami. (2020). The role of the institutional field at Dian Ayu's training and training institute in Sidenreng Rappang Regency. Jurnal Edukasi Nonformal, 1(1), 122-138. doi:http://ummaspul.ejournal.id/JENFOL/article/view/217

Alawamleh, H. S., Bdah, A., \& Alahmad, N. (2013). The Impact of Planning on the Quality of Educational Programs at Al- Balqa' Applied University. International Journal of Business Administration, $\quad 4(5), \quad 38-50 . \quad$ doi: http://dx.doi.org/10.5430/ijba.v4n5p38 
Aningtiyas, E. S., Fakhruddin, \& Ilyas. (2012). Management of music courses (studies at 99 music course institutes J1. Pattimura Raya Ungaran Semarang Regency). NFECE: Journal of NonFormal Education and Community Empowerment, 1(1), 1-6. Retrieved from http://journal.unnes.ac.id/sju/index.php/jnfc/article/view/2803

Arya, M., \& Endrawijaya, I. (2017). Studies onboarding facilities services at the Indonesian Aviation College. Jurnal Ilmiah Aviasi Langit Biru, 2, 28-39. Retrieved from http://journal.ppicurug.ac.id/index.php/jurnal-langitbiru/article/view/227

Asshidiqy, M. S. (2016). The role of the Surabaya Hotel School course and training institution in increasing the absorption of labor into the hotel industry in the housekeeping field abroad. J+Plus Unesa, 5(1), 1-9. Retrieved from https://jurnalmahasiswa.unesa.ac.id/index.php/jurnalpendidikan-luar-sekolah/article/view/16575

Ball, A. L., Knobloch, N. A., \& Hoop, S. (2007). The instructional planning experiences of beginning teachers. Journal of Agricultural Education, 48(2), 56-65.

Bij, T. v., Geijsel, F. P., \& Dam, G. T. (2016). Improving the quality of education through self-evaluation in Dutch secondary schools. Studies in Educational Evaluation, 49, 42-50. doi:https://doi.org/10.1016/j.stueduc.2016.04.001

Dalle, J., \& Mutalib, A. A. (2018). The impact of technologies in teaching interaction design. Journal of Advanced Research in Dynamical and Control Systems, 4(special issue), 1779-1783.

Delfino, A. P. (2019). Student engagement and academic performance of students of Partido State University. Asian Journal of University Education, 15(3), 42-55. doi: 10.24191/ajue.v15i3.05

Directorate General of Courses and Trainings. (2019, October 3). Importance of data for course and training institutions in Online Education Main Data. Retrieved from Ministry of Education and Culture of Indonesian Republic: https://kursus.kemdikbud.go.id/index.php/3134/pentingnyadata-lkp-di-dapodik-online/

Escobar, I. H. (2019). School improvement plans, a tool to improve the quality of education. New Trends and Issues Proceedings on Humanities and Social Sciences, 6(1), 440-450.

Filho, W. L., Skanavis, C., Kounani, A., Brandli, L. L., Shiel, C., Paço, A. d., . . . Shula, K. (2019). The role of planning in implementing sustainable development in a higher education context. Journal of Cleaner Production, 235, 678-687. doi:https://doi.org/10.1016/j.jclepro.2019.06.322

Fredian, O. D. (2018). Management of collaboration between vocational schools majoring in music and the business/industrial world in increasing the job prospects of graduates at SMKN 12 Surabaya. Jurnal Inspirasi Manajemen Pendidikan, 6(3), 1-15. Retrieved from jurnalmahasiswa.unesa.ac.id/index.php/inspirasi-manajemenpendidikan/article/view/26471/24244

Grajcevci, A., \& Shala, A. (2016). Formal and Non-Formal Education in the New Era. Action Researcher in Education, 3(7), 119-130.

Gustini, D. E., Alexon, \& Trudjai. (2017). Evaluasi program English for Children di Colorado Course. DIADIK: Jurnal Ilmiah Teknologi Pendidikan, 7(2), 12-18. Retrieved from https://core.ac.uk/download/pdf/228575265.pdf

Hadi, S. (2012). Evaluation of the implementation of the competency-based curriculum in the DIY automotive course and training institute. Jurnal Pendidikan Vokasi, 2(2), 267283. doi:10.21831/jpv.v1i1.1036

Hamalik, O. (2008). Curriculum development management. Bandung: Remaja Rosdakarya.

Hapsari, M. I. (2017). Assessment of course and training programs related to types of skills, certification, and job placement. Journal of Nonformal Education, 2(1), 71-82. Retrieved from http://journal.unnes.ac.id/nju/index.php/jne

Hatimah, I., \& Sadri. (2014). Community-based learning. Jakarta: Universitas Terbuka.

Herlina. (2018). The urgency of partnerships for the development of non-formal educational institutions. Transformasi: Jurnal Penelitian dan Pengembangan Pendidikan Non Formal, 3(1), 1-15. Retrieved from http://jurnal.ikipmataram.ac.id/index.php/transformasi/article/ viewFile/651/612

Herlinda, S., Hidayat, S., \& Djumena, I. (2017). Training management is delivered in improving the life skills of learning citizens in courses and training institutions. Journal of Nonformal Education and Community Empowerment, 1(1), 1-9. doi:10.15294/pls.v1i1.14758

Husein, A., \& Sutarto, J. (2017). Learning sewing courses at the Nissan Fortuna, Kudus Regency training and training institute. Jurnal Eksistensi Pendidikan Luar Sekolah (E-Plus), 2(1), 3038. doi:10.30870/e-plus.v2i1.2946

Irianto, J. (2011). Human Resource Management. Surabaya: Insan Cendekia.

Ishak, A. (2012). Action research in non-formal educational institutions. Jakarta: Raja Grafindo Persada.

Istiqomah, N., Fakhruddin, \& Utsman. (2017). Evaluation of the quality of equality education services at PKBM Citra Ilmu in Semarang. JNE: Journal of Nonformal Education, 3(2), 149157. doi:10.15294/jne.v3i2.10950

Jayadi, H., Zulkarnain, R., \& Sofino. (2017). The efforts of the EEC LKP management to get accreditation A from BAN PAUD and PNF. JPM: Journal of Community Development, 1(1), 88-97. Retrieved from https://ejournal.unib.ac.id/index.php/jpls/article/view/4044/22 $\underline{48}$ 
Kamil, M. (2010). Education and Training Model. Bandung: Alfabeta.

Kaplan, L. S., \& Owings, W. A. (2001). Teacher quality and student achievement: recommendations for principals. NASSP Bulletin, 85(628), 64-73. doi:10.1177/019263650108562808

Latchem, C. (2014). Informal learning and non-formal education for development. Journal of Learning for Development-JLAD, 1(1). $\quad$ Retrieved from http://j14d.org/index.php/ej14d/article/view/6

Mahmudah, N. (2016). Understanding of Ar-Rum course and training institute managers of the institution's quality assurance program. Jurnal Elektronik Mahasiswa, 5(7), 264-273. Retrieved

from http://journal.student.uny.ac.id/ojs/index.php/pls/article/view/ $\underline{3475}$

Miles, M. B., Huberman, A. M., \& Saldana, J. (2014). Qualitative data analysis, a methods sourcebook. New York: Sage Publications.

Minister of Education and Culture. (2013). Regulation of the minister of education and culture of The Republic of Indonesia number 81 of 2013 concerning the establishment of a nonformal education unit. Jakarta: Minister of Education and Culture of the Indonesian Republic.

Ministry of Education and Culture. (2016). Technical guidelines for improving the quality of management and learning of course and training institutions towards national standards. Jakarta: Directorate of Course and Training Development.

Moldovana, O., \& Boco, V. (2015). The necessity of reconsidering the concept of non-formal education. Procedia - Social and Behavioral Sciences, 209, 337-343. doi: 10.1016/j.sbspro.2015.11.245

Nepal, B., \& Maharjan, R. (2015). Effect of school's physical facilities on learning and outcomes of students in Nepal. Journal for Studies in Management and Planning, 1(6), 266279.

Ningrum, M. K. (2015). Evaluation of a sewing course program to empower women at the Aniq Sidoarjo Modes Training and Training Institute. J+Plus Unesa, 4(1), 1-12. Retrieved https://jurnalmahasiswa.unesa.ac.id/index.php/jurnalpendidikan-luar-sekolah/article/view/11307/10736

Notoatmodjo, S. (2010). Health Behavior and Education. Jakarta: Rineka Cipta.

Poernamawijaya, L. W., Sulaiman, S., Suriansyah, A., \& Dalle, J. (2018). Contribution on supervision of the supervisor, principals motivation, kindergarten teacher performance to improving the kindergarten quality in West Banjarmasin, Indonesia. European Journal of Alternative Education Studies, 3(2), 129-146. doi:10.5281/zenodo.2261031

Pradikto, B. (2017). The efforts of the Cimahi City Dress Making course and training institute in increasing entrepreneurial motivation. Seminar Nasional Pendidikan Nonformal (pp. 76-
84). Bengkulu: Fakultas Keguruan dan Ilmu Pendidikan Universitas Bengkulu. Retrieved from http://repository.unib.ac.id/11769/

Prihantoro, R. (2012). Quality control concept. Bandung: Remaja Rosdakarya.

Putra, A. K., \& Hariyati, N. (2017). The role of community relations in improving the quality of school collaboration with the Business and Industrial World (DUDI) at SMK Negeri 5 Surabaya. Inspirasi Manajemen Pendidikan, 5(1). Retrieved from https://jurnalmahasiswa.unesa.ac.id/index.php/inspirasimanajemen-pendidikan/article/view/21864

Rizaldi, W., \& Sutarto, J. (2017). Management of computer course learning at the Alfabank Semarang city course and training institute. Jurnal E-Plus: Eksistensi Pendidikan Luar Sekolah Universitas Sultan Ageng Tirtayasa, 2(2), 116-213. doi:10.30870/e-plus.v2i2.2958

Rosyid, M. K., Faizin, M. S., Nuha, N. U., \& Arifa, Z. (2019). Active learning planning management at the Al-Azhar Pare Arabic Language Course in Kediri. Lisania: Journal of Arabic Education and Literature, 3(1), 1-20. doi:10.18326/lisania.v3i1.1-20

Saad, A. M., Yusoff, N. R., \& Yassin, R. M. (2011). Assessment of ease of learning, financial allotment, and courses in service for Islamic education courses at Malaysian Polytechnic. Journal of Islamic and Arabic Education, 3(1), 123-134. Retrieved from https://core.ac.uk/download/pdf/11491713.pdf

Sa'dhiyah, A. (2016). The BBL partnership model (bridging, bonding, linking) in the development of course programs at SKB Salatiga City. Homeschooling Versus Formal School; a dialog about high-quality education (pp. 119-126). Retrieved from $\quad$ http://pnf.unnes.ac.id/wpcontent/uploads/2016/12/PROSIDING-PLS-UNNES-2016min.pdf\#page $=134$

Sa'idah, R. (2017). Efforts to create quality Arabic learning (the study of Arabic learning at the Al-Farisi Pare Arabic Language Course Institute). Reality: Islamic Research and Culture Journal, 16(1), 1-16. doi:10.30762/realita.v15i1.463

Satria, R. P., Supadi, \& Listyasari, W. D. (2017). Partnership in implementing school based management at SMA Al-Azhar Kelapa Gading, North Jakarta. iMProvement: Jurnal Ilmiah untuk Peningkatan Mutu Pendidikan, 4(2), 140-152. Retrieved from http://journal.unj.ac.id/unj/index.php/improvement

Septyana, H. (2013). Management of sewing competency-based learning at the private job training institute (LPKS) Fortuna Dukuh Siberuk, Siberuk Village, Batang Regency. Journal of Nonformal Education and Community Empowerment, 2(2), 46-50. Retrieved from https://journal.unnes.ac.id/sju/index.php/jnfc/article/view/226 $\underline{5}$

Serbes, M., \& Albay, M. (2017). Importance of career planning and development in education. International Journal of Social 
Sciences \& Educational Studies, 4(2), 149-154. doi:10.23918/ijsses.v4i2sip149

Sucipto, N. R., \& Sutarto, J. (2015). Empowerment of the poor to improve life skills through sewing courses at the Elisa Tegal Training and Training Institute. NFECE: Journal of NonFormal Education and Community Empowerment, 4(2), 135142. Retrieved from http://journal.unnes.ac.id/sju/index.php/jnfc

Sudarsana, I. K. (2016). Improving the quality of education outside of school to develop human resources. Quality Guarantee Journal, 1(1), 1-14. Retrieved from http://www.ejournal.ihdn.ac.id/index.php/JPM/article/downlo $\mathrm{ad} / 34 / 43$

Sudjana, D. (2004). Evaluation of educational programs (for nonformal education and human resource development). Bandung: Falah Production.

Sufyan, M. A., Nurhalim, K., \& Shofwan, I. (2019). Learning management of non-formal education units in learning activities. Journal of Nonformal Education, 5(1), 57-66. doi:10.15294/jne.v5i1.18335

Sujanto, A. (2016). Development of partnerships for courses and training institutions with business and industry for quality assurance. Jurnal AMIK JTC, 12(2), 59-65. Retrieved from http://amikjtc.com/jurnal/index.php/jurnal/article/view/110

Trianto. (2010). Designing innovative-progressive learning models. Jakarta: Kencana Prenada Media Group.

Wahyuni, S., \& Sutarto, J. (2018). Learning sewing courses at the Gassebo training and training institute, Kendal district. JPPM: Jurnal Pendidikan Pemberdayaan Masyarakat, 5(2), 23-44. doi:10.36706/jppm/v5i2.8275

Wiyoko, E. P. (2010). Evaluation of the learning program. Yogyakarta: Pustaka Pelajar.

Yulianingsih, W. (2017). Implementation of sewing life skills education programs for women in increasing the independence of students in the Modes Muria Sidoarjo-East Java Course and Training Institute. Education Journal for All, 1(1), 29-36. Retrieved from https://journal.unesa.ac.id/index/php/jpls/article/view/2410.

Yusra, Y. L., Sumarno, \& Burhanuddin, D. (2017). Analysis of the management of educational institutions outside the BI Production Pekanbari Foundation for Dance. Jurnal Manajemen Pendidikan: Penelitian Kualitatif, 2(1), 128-133. Retrieved from $\underline{\text { http://jmppk.ejournal.unri.ac.id/index.php/JMPKK/article/vie }}$ $\underline{\mathrm{w} / 5024}$ 